MÜZEKKI'N-NÜFÛS BAĞLAMINDA EŞREFOĞLU RÛMÎ'YE GÖRE MARIFET

The Marifa According to Eshrefoglu Rumi in the Context of His "Muzekki'n-Nufus"

Arş. Gör.

\title{
YAKUP PEKDOĞRU
}

Karamanoğlu Mehmetbey Üniversitesi, İslami Ilimler Fakültesi

orcid.org/0000-0002-4251-8807

ypekdogru@gmail.com 
Öz

Marifet sûfilere göre Allah tarafindan salike verilen bir bilgidir ve bu bilgi fikıh ve kelam âlimlerinin sahip olduğu bilgiden daha değerlidir. Fıkıh ve kelam uleması bilgiye ya doğrudan temel kaynaklardan ya da istidlal yoluyla ulaşmaktadır. Sûfîler ise marifete kötülüklerin kaynağı olan nefs terbiye edildikten sonra ulaşır. Bu yöntem aynı zamanda ahlaklı bireyleri de meydana getirir; nihayetinde insan-1 kâmiller ortaya çıkar. Marifet Hakk'1 isim ve sıfatlarıyla bilmek ve şeylerin gerçekliğini kavramaktır; onun mahalli sufilerin ifadesiyle kalptir. Bu makalede Osmanlı Devleti'nin erken dönemlerinde yaşayan, Eşrefoğlu Rûmînnin Müzekki’n-Nüfûs isimli eseri bağlamında marifet görüşü incelenmiştir. $\mathrm{O}$, Hac1 Bayram-1 Veli’nin damadı ve öğrencisidir, hem şair hem sûfîdir, birçok öğrenci yetiştirmiştir, Bayrami ve Kadiridir. Onun eseri seyr u süluk kitabı olarak kabul edilebilir; zira bu eserde nefsi terbiye eden konular ayrıntılı olarak ele alınmıştır. Ayrıca eserin dikkat çekici bir özelliği de okuyuculara çokça nasihatte bulunmasıdır. Eşrefoğlu Rûmî’nin kitaptaki amacı kişileri doğru yola iletmek ve ahirette kurtuluşlarını sağlamaktır. Dolayısıyla biz de çalı̧̧mamızda eserin bu yönüne değindik. Daha sonra Eşrefoğlu Rûmînnin marifete dair görüşlerini açıkladık.

Anahtar Kelimeler: Marifet, İlham, Süluk, Eşrefoğlu Rûmî, Müzekki’n-Nüfûs.

\begin{abstract}
According to sufis, the marifa is a knowledge given by Allah, and it is more valuable than knowledge generated by fiqh and kalam scholars. Fiqh and kalam scholars gains knowledge either through the basic sources, which are mainly Qur'an and sunnah, or istidlal (deduction). The sufis obtain this knowledge/marifa after thenafs has been educated. This method also generates well-behaved people and ultimately perfect humans reveal. arifa is to know names and attributes of Allah and to realize the truth of the things. According to the sufis, the locus of marifa is the heart. This study will examine the opinion of Eshrefoglu Rumi, who lived in the early periods of the Ottoman Empire, on marifa/knowledge depending upon his book named Muzekkin-Nufus. He is the groom and disciple of Haji Bayram Wali and both a poet and a sufi. Being affiliated with Bayrami and Qadiri orders, he has educated a lot of disciples. His work can be accepted as a book of sayr u suluk (the spiritual journey) because in this work the topics related to spiritual purification are explained in a detailed way. Furthermore, giving much advice to the readers makes the work remarkable. The aim of Eshrefoglu Rumi in his book is to convey people to the straight path and provide their salvation in the hereafter. Hence, in this article we focused on this aspect and later on, we explained the topics related to the marifa from the perspective of Eshrefoglu Rumi.
\end{abstract}

Keywords: Marifa, Ilham/Inspiration, Suluk, Eshrefoglu Rumi, Muzekkin-Nufus. 


\section{Giriş}

Tasavvuf diğer İslami disiplinlere göre geç dönemde sistemleşmiş ve eserlerini vermeye başlamıştır. Dolayısıyla dini düşünceye taalluk eden hususlara dair yeni yorumlar ve bu minvalde yeni kavramlar üretmiştir. Tasavvuf bunun yanında bilgiye dair de kendine has bir metot geliştirmiştir. İslam düşüncesinde "nas" bilgi olarak kabul edilirken uzmanlar nastan hareketle nazar yöntemiyle de bilgi oluşturmaktadır. Sûfiler ise bütün kötülüklerin kaynağının nefs olduğunu söyler ve nefsin terbiye edilmesiyle marifet denilen bilginin oluşabileceğini iddia eder. ${ }^{1}$

Eşreoğlu Rûmî de sûfilerin marifet için geliştirdikleri bu yöntemi benimsemektedir. O, Osmanlı Devleti'nin ilk dönemleri diyebileceğimiz bir zamanda yaşamı̧s ve hem ilmi yönden hem de tasavvufi yönden kendisini geliştirmiştir. Özellikle tasavvufi yönü herkes tarafindan bilinmekte olup bu alanda da Müzekki'n-Nüfûs gibi herkese hitap eden bir eser kaleme almıştır. Makalemizde Eşrefoğlu Rûmî’nin Müzekkin-Nüfûs isimli eseri özelinde marifete dair görüşlerinin ne olduğu tanitılacaktır.

\section{Müzekki’n-Nüfûs ve Marifete Ulaşmada Yöntem}

Eşrefoğlu Rûmî̀nin önemli eserlerinden bir tanesi MüzekkinnNüfûs'tur. Eşrefoğlu bu eserini iki bölüme ayırmaktadır. Birinci bölümün ana unsurları dünya ve nefs-i emmaredir. Bunun yanında ölüm, kıyamet, cennet, cehennem ve tevekkül gibi konular da bulunmaktadır. İkinci bölüm ise nefsin terbiye edilmesi, mürit-mürşit ilişkisi, zikir, riyazata dahil olan az yeme, az uyuma, az konuşma ve halvet gibi hususlara benzer meselelere ayrılmışır. ${ }^{2}$

Her eserin ortaya çımasında belli sebepler bulunur. Bu sebepler arasında ilmi gayeler olduğu gibi yazarın hitap ettiği kesime nasihat

Ethem Cebecioğlu, Tasavvuf Terimleri ve Deyimleri Sözlüğ̈, Otto Yay., Ankara 2014, s. 319, 363-364.

2 Abdullah Rumi b. Seyyid Ahmed Eşref b. Seyyid Muhammed Süyufi, Müzekki'n-Nüfûs, haz.: Ahmet Kasım Fidan, Semerkand Yay., İstanbul 2015, s. 65; Abdullah Uçman, “Müzekki'n-Nüfus”, DIA., Türkiye Diyanet Vakfı Yayınları, İstanbul 2006, c. 32, s. 246. 
verme amacı da bulunmaktadır. Müzekki'n-Nüfûs da daha çok nasihat verme amacını taşıyan eserlerden birisidir. Eşrefoğlu Rûmî yaşadığ1 dönemde toplumda meydana gelen bozulmaların farkındadır ve bunlardan rahatsızdır. Bozulmalardan bazısı tasavvufun klasik olarak kabul edilen eserlerdeki sûfilerin ya da müellif sûfilerin dile getirdiği eleştirilere benzemektedir. Hakikatte arif ya da mürşit olmayan kimselerin arif gibi davranması ve bu davranışla dünyevi menfaat elde etmesi bu duruma örnek verilebilir. ${ }^{3}$ Esasen ulemada, yöneticilerde başta olmak üzere hayatın bütün yönün kuşatan alanlarda bir bozulmaya işaret eden Eşrefoğlu Rûmî Müzekkinn-Nüfûs'u yazma nedeni olarak şunu belirtmektedir: "Zaman azdı, kardeşlerimizin halleri değişti. Azgınlık ve münafiklık çoğaldı. Mürşid-i kâmil kalmadı. Mürşid-i kâmile ve sözüne itibar yok. Beyler zalim oldular, kadılar rüşvet yer, ilme uymazlar. İlmi kendi heveslerine alet ettiler. Müderrisler fâsık oldu. Tefsir ve hadis medreselerde okutulmuyor. Fakihler ve din ilmini bilenler azaldı. Vaizler dünya için vaaz verip para toplarlar. İlmiyle beylerin, zabitlerin ve halkın arasında rağbet görmeyen danişmentler şeyhlik yolunu tuttular. Hile yolu ile halkın elindekileri kolaylıkla alırlar. Kendilerinde aynı haller varmış gibi gerçek şeyhlerin sözlerini ezberleyerek meclislerde söylerler. Kendilerini halka ehl-i hal olarak gösterip mürit ve muhip ederler. Başına birkaç talip toplayan gerçek arif elbisesini giydiğini zannetti. Bunlar zikir meclislerinde olgunluk gösterisi olarak sessizce oturup riya ile başlarını sallarlar. Maksatları halk arasında şöhret bulmaktır. Kendileri için "filan şeyh bu asrın bir tanesidir" diye söyletirler. Bütün bu arzuları dünyalıktır. Etraftan elbise ve armağanların gelmesidir."

Eşrefoğlu Rûmî eserini yukarıda belirttiğimiz gerekçelerle Türkçe yazdığını özellikle belirtmektedir. Çünkü o, Müzekki'n-Nüfûs'un sadece belli bir seviyeye gelmiş ulema zümresine değil halkın bütününe faydalı olmasını istemektedir. Aslında o, bu kitabıyla mevcut bozulmaların ortadan kaldırıp kendi deyimiyle insanları "nefs-i emmareden kurtarıp nefs-i mutmainneye" ulaştırmak istemektedir. ${ }^{5} \mathrm{Bu}$ isteğini eserdeki ko-

\footnotetext{
Örnek için bkz.: Ebû Tâlib Muhammed b. Ali b. Atıyye el-Hârisî el-Mekkî, Kûtül-kulûb fî muâmeleti'l-mahbûb ve vasfu tarîki'l-mürîd ilâ makâmi't-tevhîd (Kalplerin Aziğı), trc.: Dilaver Selvi-Yakup Çiçek-Ali Kaya, Semerkand Yay., İstanbul 2011, c. 2, s. 30, 134.

${ }^{4}$ Eşrefoğlu Rûmî, Müzekki'n-Nü̈ûs, s. 63.

5 Eşrefoğlu Rûmî, Müzekki'n-Nüfûs, s. 64.
} 
nuları anlatırken Kur'ân ve sünnetten deliller getirdiğini hem ashabın hem de şeyhlerin sözlerine yer vererek yerine getirmektedir. Bunun yanında kitaba muhatap olan kitleye de bir uyarısı bulunmaktadır: Eşrefoğlu Rûmî kitap içerisindekilerin kimileri için anlaşılmaz olacağını düşünür. Bu sebeple eseri okuyanların onlardan bu kitabını koruması gerektiği yönünde nasihati bulunmaktadır ki o kimseler kitapta yer alan ifadeleri reddederek nifak ya da günaha düşmesinler. ${ }^{6}$

Müzekki’n-Nüfûs'un iki bölümden oluştuğuna ve ilk bölümde Eşrefoğlu Rûmî’nin dikkat çektiği temel hususların nefs ve dünya olduğuna yukarıda değinilmişti. İlk dönem sûfilerin ittifakla kabul ettiği ve 1srarla vurguladığı nefsin bütün kötülüklerin kaynağı olduğu düşüncesine ${ }^{7}$ Eşrefoğlu Rûmî de katılmaktadır. Bu sebeple o, nefsin temizlenmesine eser boyunca sıklıkla vurgu yapar. Ona göre nefs dört kısma ayrilır. Bunlar sırasıyla nefsi-i emmare, nefs-i levvame, nefs-i mülhime ve nefs-i mutmainnedir. ${ }^{8}$ Nefs-i emmare sahibi bir kişi onun belirttiği usule göre kendisini terbiye ederse nefs-i mutmainne makamina ulaşabilir. ${ }^{9}$

Dünya hakkındaki Eşrefoğlu Rûmî’nin görüşleri yine ilk dönem sûfilerin görüşleriyle paraleldir. ${ }^{10}$ İlk dönem meşhur mutasavvıfların-

6 Eşrefoğlu Rûmî, Müzekki'n-Nüfûs, s. 68.

7 Ebü'l-Kâsım Zeynülislâm Abdülkerîm b. Hevâzin el-Kuşeyrî, er-Risâletü'l-kuşeyriyye (Tasavvuf İlmine Dair Kuşeyrî Risâlesi), trc.: Süleyman Uludağ, Dergah Yay., Istanbul 2009, s. 181.

8 Eşrefoğlu Rûmî, Müzekki'n-Nüfûs, s. 25. Nefsin mertebelerinde yedili tasnif daha meşhurdur ama temel tasavvuf kitaplarında bu yedili sistem yer almaz. Nefsin yedili mertebesine "atvar- seb'a" denilir ve şu şekildedir: "Nefs- Emmare, nefs-i levvame, nefs-i mülhime, nefs-i mutmaine, nefs-i razıye, nefs-i marzıyye, nefs-i kamile." Bkz.: Süleyman Uludağ, "Nefis”, DİA., Türkiye Diyanet Vakfi Yayınları, İstanbul 2006, c. 32, s. 528. Ayrıca Halvetiyye geleneğinde meşhur olan atvar-1 seb'a hakkında yapılan çalışma için bakınız: İbrahim Işıtan, "Halvetiyye Geleneğine ve Bir Halveti Şeyhi Olan Sofyalı Bâli Efendi’ye Göre Sülukun Yedi Evresi”, Marife: Dini Araştırmalar Dergisi, 2010, c. 10, sayı: 1, s. 91-109. Ayrıca Eşrefoğlu Rûmî tevbenin anlamının nefsin kötü ahlakının iyi ahlaka tebdil edilmesi olduğuna vurgu yapar. Bkz.: Harun Alkan, "Eşrefoğlu Rumi’nin Müzekki'n-Nüfus Adlı Eserinde Tevbe Kavramı”, III. Uluslararası Hacı Bayrâm-ı Veli Sempozyumu Bildiriler Kitabı, Ankara 2018, s. 173.

9 Eşrefoğlu Rûmî, Müzekkinn-Nüfûs, s. 25-54; Süleyman Derin, "Hacı Bayram Veli'nin Damadı Eşrefoğlu'nda Nefsin Terbiye Metotları", II. Uluslararası Hacı Bayram-ı Velî Sempozyumu Bildiriler Kitabı 2, Ankara 2017, s. 31-54; İbrahim Baz, "Eşrefoğlu Rûmî”nin Müzekki'n-Nüfûs İsimli Eserinde Nefs-i Emmâre'nin Özellikleri ve Islahı”, IV. Uluslararası Hacı Bayram-ı Velî Sempozyumu, Ankara 2019, s. 121-135.

${ }^{10}$ Ayrıca mürşidi Hacı Bayram-1 Veli’nin dünya görüşüyle de uyuşmaktadır. Bkz.: Öncel Demirdaş, "Hacı Bayrâm-1 Veli'de Dünya Algısı", II. Uluslararası Hacı Bayram-ı Velî Seтроzүити Bildiriler Kitabı 1, Kalem Neşriyat, Ankara 2017, ss. 273-277. 
dan Zünnun Misrî kendisine dünya ile ilgili sorulan soruya verdiği cevapta sûfilerin genel itibariyle dünya hakkındaki görüşlerini ortaya koyar: "Dünya nedir dediklerinde, Misrî, "Seni Allah'tan alıkoyan her şey" der. ${ }^{11}$ Eşrefoğlu Rûmî dünyanın nefs-i emmareyi etkileyen bir yapısı olduğunu düşünür ve bu nefisteki kötü özelliklerin dünya ve dünya sevgisinden kaynaklandığına vurgu yapar. Ona göre Allah dünyayı sevmemektedir ve bunun nedeni de "dünyanın talipleri aldatmasıdır."12 Bunun için ısrarla Eşrefoğlu Rûmî dünya hakkında uyarılar yapmaktadır ve ondan tamamıyla vazgeçilmesi gerektiğini belirtmektedir. ${ }^{13}$ Müzekki’n-Nüfûs'un ilk bölümünde yer alan diğer konular ise ölümden sonraki hayatta rahata kavuşmak için yine nefsin terbiye edilmesi gerektiğine yönelik nasihatleri içermektedir. Dahası konular bu minvalde işlenmektedir.

Müzekki'n-Nüfûs'un ikinci bölümü seyr u sülûkun ${ }^{14}$ unsurlarının kendisini daha fazla hissettirdiği yer olarak karşımıza çıkmaktadır. Eşrefoğlu Rûmî kişinin sorumlu olduğu ibadetlerin yanı sıra hem ahlaki yetkinliğin sağlanması hem de kâmil bir mürşitlik için bu terbiye usullerini anlatmaktadır. Bunlar arasında nefse muhalefet başta olmak üzere her an icra edilebilmesi özelliğiyle zikir ön plandadır. ${ }^{15}$ Bunun yanında riyazatın unsurları olan ve peygamberlerin özelliği olarak kabul edilen az yeme, az konuşma, az uyuma ve halvet ya da uzlet seyr u sülûkun önemli birer unsurları olarak eserde ayrıntılı bir şekilde incelenmektedir. Bu konulara ilaveten Eşrefoğlu Rûmî’nin çok önemsediği mürşit konusu da detaylı olarak zikredilmektedir.

Bütün bu hususların uygulanmasından sonra Eşrefoğlu Rûmî iki hususa dikkat çeker: Birincisi iki kavrama dikkat çektiği husustur: "İyi ah-

${ }^{11}$ Ebu Hamid Feridüddin Muhammed b. Ebi Bekr İbrahim-i Nisaburi, Tezkiretü’l-Evliya, trc.: Süleyman Uludağ, Kabalcı Yay., İstanbul 2007, s. 168.

${ }^{12}$ Eşrefoğlu Rûmî, Müzzekki'n-Nüfüs, s. 78. Şeyhi Hac1 Bayram-1 Veli'nin bu konu hakkındaki görüşü bkz.: Ahmet Cahid Haksever, "Hac-1 Bayram-1 Veli'nin Şiirlerinde Tasavvufi Mertebeler", Uluslararası Hacı Bayram-ı Veli Sempozyumu Bildiriler Kitabı 2, Ankara 2016, ss. 21-22.

${ }^{13}$ Eşrefoğlu Rûmî, Müzekkin'n-Nüfûs, s. 77-110.

${ }^{14}$ Seyr ü süluk: "Bir şeyhin nezaretinde, Allah'a vuslat için çıkılan yolculuk" ya da "Hakk'a ermek için bir rehberin öncülüğünde ve denetiminde çıkılan manevi yolculuk" anlamlarında kullanılmaktadır. Bkz.: Süleyman Uludağ, Tasavvuf Terimleri Sözlüğ̈̈, Kabalc1 Yay., İstanbul 2012, s. 316; Cebecioğlu, a.g.e., s. 433.

${ }^{15}$ Eşrefoğlu Rûmî, Müzekki'n-Nüfûs, s. 291-308, 407-436. 
lak" ve "kötü ahlak." Seyr u sülûk süreci marifete erişmek için bir yöntem olduğu gibi iyi ahlaka sahip insanları da meydana getirmektedir. Ancak kişilerde ortaya çıkan "iyi ahlakın" sürdürülebilirliği gerekmektedir. Eşrefoğlu Rûmî bu konuya çokça ehemmiyet göstermektedir. Ona göre nefsini terbiye eden ve Hakk'tan sayılamayacak lütuflara ulaşan kimse seyr u sülukunun bittiği düşüncesine kapılmaması gerekir. Çünkü ulaştığ1 makam son değildir ve makamların sonu yoktur. Dolayısıyla sülukun sürekliliğine vurgu yapar ve onun şu ifadesi anlatmaya çalıştığımız konuyu izah etmektedir: "Bir talibin yüz yıl ömrü olsa bu yüz yıllık ömrünün hepsini sülûk ederek geçirse ve yüce yüce makamlara ulaşsa, o makamlara hiçbir velinin ulaşamadığını düşünse bile sülûke daha yeni başladığını kabul etmelidir." ${ }^{\prime 6}$ İkincisi ise sürecin sonunda bilginin ya da ilhamların gelmesidir. Eşrefoğlu ilhamın gelmesi için nefsin mülhime makamında olmasını şart koşar. Çünkü bu makamda nefs-i emarenin kötü sıfatları yok olmuş ve kalp bilgiye hazırlanmıştır. ${ }^{17}$

\section{Eşrefoğlu Rûmî’ye Göre Marifet}

\subsection{Marifet Nedir}

Marifet kelime olarak "bilmek, tanımak, ikrar etmek, bilgi” anlamlarına gelir. Marifete benzer bir kavram da ilimdir. İlim "bilgi, bir şeyi gerçek yönüyle kavramak" şeklinde anlamlara sahiptir ve marifet gibi genel olarak bilgi anlamında kullanılır. ${ }^{18}$ Marifet tasavvuf sözlüklerinde ise şu anlamda kullanılmaktadır: "Sûfilerin ruhani halleri yaşayarak, manevi ve ilahi hakikatleri tadarak elde ettikleri bilgi ve irfandır." 19 Marifetin bu tanımı bizi bilginin oluşmasında akli bir çabanın haricinde farklı bir yöntemin varlığı hakkında bilgi vermektedir. İlim daha çok belli bir gayret sonucunda elde edilen bilgiye karşılık gelirken marifet, seyr u süluke konu olan unsurların - ibadet, riyazat, mücahede, zikir vb- uygulanması sonucunda nefsin kötü sıfatlardan

\footnotetext{
${ }^{16}$ Eşrefoğlu Rûmî, Müzekki'n-Nüfûs, s. 578.

${ }^{17}$ Eşrefoğlu Rûmî, Müzekki'n-Nüfûs, s. 51.

${ }^{18}$ Ebu'l-Fazl Muhammed b. Mükerrem b. Ali el-Ensârî İbn Manzûr, Lisânü'l-arab, Dâru'lMaârif, Kahire t.y., s. 1090, 2897; İlhan Kutluer, "İlim”, DIA., Türkiye Diyanet Vakfi Yayınları, İstanbul 2000, c. 22, s. 109; Süleyman Uludağ, "Marifet", DİA., Türkiye Diyanet Vakfi Yayınları, İstanbul 2003, c. 28, s. 54.

${ }^{19}$ Uludağ, Tasavvuf Terimleri, s. 236.
} 
arınarak Hakk'ın verdiği bilgiye karşılık gelir. Dolayısıyla sûfilerin marifet diye isimlendirdikleri bilgi "ilim" kavramının içerdiği anlamdan farklılaşır. Kimi sûfilerin ilim ve marifetin ne olduğuna yönelik yaptıkları tanımlarda bu farklılık şu şekilde yer almaktadır: "Eşyanın zâhiriyle ilgili bilgilere ilim, eşyanın bâtınını ve iç yüzünü keşfetmek suretiyle elde edilen bilgilere marifet denilir." ${ }^{20}$

Sûfiler kendi oluşturdukları yöntem sonucunda elde ettikleri bilgiyi ifade eden marifet için farklı terimler kullanmaktadırlar. Keşf/ mükaşefe, müşahede, yakîn, fetih, firaset, tecelli, batın ilmi, ledünni ilmi gibi terimler bunlar arasında yer almaktadır. ${ }^{21}$ Eşrefoğlu Rûmî de eserinde marifet için farklı kavramlar kullanmaktadır. Bunlar arasında ilham, rabbani ilham, sarih hitap, marifet, müşahede, keşf ve batın ilmi gibi terimler bulunmaktadır. ${ }^{22}$ Özellikle ilham Eşrefoğlu'nun sık kullandığı bir kavramdır. O, ilhamı yalnızca marifeti ifade edecek şekilde değil nefsin ve şeytanın da insanlara kötü karaktere sahip eylemleri uygulamada ya da hoşa gitmeyen düşünceleri akla getirmesi için ilham kavramını kullanmaktadır.

\subsection{Eşrefoğlu'na Göre Hem Marifeti Hem De Vesveseyi Iffade Eden Kavram: Illham}

Ilham ilk dönemlerden itibaren sûfiler tarafindan kullanılan bir kavramdır ve "düşünmek şeklinde ulaşılan bir bilgi olmayıp Allah tarafından verilen özel bir bilgi türü” olarak kabul edilir. ${ }^{23}$ İlham için farklı kavramlar da kullanılmaktadır. Bunlar arasında en sık kullanılanı havatırdır. Dahası Kuşeyrî̀nin ifadesine göre havatır, ilhama göre daha genel bir kavramdır. O, havatırı "kalplere gelen bir hitap" olduğunu söyler ve havatırın melekten gelmesine de "ilham" demektedir. ${ }^{24}$

Yukarıda belirtildiği gibi Eşrefoğlu Rûmî ilham kavramını sıklıkla kullanmaktadır. Ona göre ilhamın beş türü vardır. Bunlar ise nefsani

${ }^{20}$ Ebû Bekr Muhammed b. İbrâhim el-Buhârî el-Kelâbâzî, et-Taarruf li-mezhebi ehli'ttasavvuf (Doğus Devrinde Tasavvuf), Dergah Yay., İstanbul 2016, s. 109.

${ }^{21}$ Uludağ, "Marifet", s. 54; Mustafa Çakmaklığlu, İbn Arabì'de Márifetin Ifadesi, İnsan Yay., İstanbul 2011, s.194.

${ }^{22}$ Eşrefoğlu Rûmî, Müzekkinn-Nüfûs, s. 42, 43, 320, 417, 450.

${ }^{23}$ Uludağ, Tasavvuf Terimleri, s. 184.

${ }^{24}$ Kuşeyrî, er-Risâle, s. 177. 
ilham, şeytani ilham, meleki ilham, kalbi ilham ve rabbani ilhamdır. Eşrefoğlu, Kuşeyrî'nin zikrettiği havatır kavramına eserinde yer vermez. Dolayısıyla o, meleki ilhamın Kuşeyrî̀nin belirttiği havatırla ilişkisine dair bir fikir beyan etmez. Bunun yanı sıra Eşrefoğlu'nun taksim ettiği ilham türlerinden nefsani, şeytani ve meleki olanlar içerik itibariyle Kuşeyrî̀nin ilham taksimatıyla benzerlik gösterir. ${ }^{25}$ Lakin Kuşeyrî'de Eşrefoğlu'nun zikrettiği kalbi ve rabbani ilham yer almaz. Müellifimiz Eşreoğlu, meleki ilham dişındaki nefsani, şeytani, kalbi ve rabbani ilhamlar hakkında eserinde az ya da çok bilgi vermektedir. Ancak meleki ilhamın varlığından bahsetse de ona dair bir açıklama sunmamaktadır.

Eşrefoğlu ilhamın bu türlerini şu şekilde açıklamaktadır: Nefsani ilham; bütünüyle vesveseden ibarettir. Taliplere zarar verir ve bu sebeple kaçmak gerekir. O, kitabı okuyanlara nasihat olması açısından aynı zamanda nefsani ilhamın alametlerini de açıklamaktadır. Eşrefoğlu'nun bu konudaki ifadeleri şu şekildedir: "Talibi vesveseye düşürür. Çeşitli şeylere teşvik eder, teşvik ettiği şeyde acele ettirir. Vesvesesini yerine getirttirir. Bir başka suretle ikincisine teşvik eder. Böylece bir isteğine ulaşınca bir diğerini icat eder. Bir isteği yerine getirilmezse, yüz yıl ömrü olsa başka bir isteğe geçmez." ${ }^{26}$ Eşrefoğlu'nun ifadelerinde nefsani ilhamın teşvik ettiği hususun uygulanmasındaki 1srarı dikkat çekmektedir.

Şeytani ilham; fesatlık getiren bir ilhamdır. Bu ilham talipleri kötülüğe yönlendirir. Yine taliplerin faydalanması için şeytani ilhamın alametlerini şu şekilde açıklamaktadır: "Şeytan senin gönlüne vesvese verir. Eğer onu yaptıramazsa bir başka şekilde dener. Onu da yapmazsa başka bir şekilde vesvese verir. Halbuki isteği aynıdır. Bin kere reddetsen başka bir yoldan seni zorlar. Kötülük olarak bir şeyi yaptıramazsa hayır suretinde gelerek yaptırmaya çalışır. İlk vesvesesini gerçekleştirmek için türlü türlü yollardan çalı̧masına devam eder. Başaramazsa vazgeçmez. Terk edip gitmez. Devamlı vesvesesini tazeler. Pusuda bekler. Ne zaman firsat bulursa seni azdırır. Çoğunlukla öfkeli olduğun zamanları gözler, yavuz bir köpek gibi devamlı ürür." ${ }^{27}$ Esasında her iki tür ilham da kötü-

\footnotetext{
${ }^{25}$ Bkz.: Kuşeyrî, er-Risâle, s. 177.

${ }^{26}$ Eşrefoğlu Rûmî, Müzekki'n-Nüfûs, s. 46.

27 Eşrefoğlu Rûmî, Müzekki'n-Nüfûs, s. 48-49.
} 
lük üst kategorisi altında birleşebilir. Çünkü her ikisi de kötü bir düşünceye ya da eyleme teşvik etmektedir. Ancak isimlerinde fark olduğu gibi kişiye gelen ilhamın uygulanmasına yönelik nefs ya da şeytanın izlediği yöntemde de fark vardır. Bu fark da şeytani ve nefsani ilhamı birbirinden ayıran temel bir fark olarak kendisini göstermektedir. ${ }^{28}$

Nefsani ve şeytani ilhamların kötülüğe yönlendirmesini müellifimiz kabul ettikten sonra bunların iyi bilinmesi ve ona göre bir tedbirin alınması gerektiğini düşünür. Burada seyr $\mathfrak{u}$ sülukun önemli bir unsuru mürşit karşımıza çıkmaktadır. Eşrefoğlu Rûmîye göre talip bu durumlarda mürşidine ilhamları anlatmalı ki kötü bir davranışta bulunmasın. ${ }^{29}$ Böylece mürşit kişilerin ahlaki eğitiminin yanı sıra ilhamdan sonra kendisine başvurulan bir referans olarak sistemde önemli bir görev icra eder. Bunun yanında Eşrefoğlu nefs ve şeytan tarafindan gelen ilhamlardan korunmanın önemini hatırlatır. Bu sebeple bu ilhamlardan sürekli korunmak için o, özelde mücahede ve riyazatın genelde ise seyr u sülukun kesintisiz bir şekilde devam etmesi gerektiğini düşünür. ${ }^{30}$ Nefis kötü sıfatlardan arındıktan sonra kötülüğü özendiren hem şeytani hem de nefsani ilhamlar son bulur ve ardından ilk önce kalbi ilham gelir ve buradan hareketle marifeti ifade eden ilhamlar başlar. ${ }^{31}$

Eşrefoğlu şeytani ve nefsani ilhamdan sonra "kalbi ilham" hakkında bilgi vermektedir. Ona göre kalbi ilham "daima Hakk’1 anmakla talibi marifete ve hikmete sevkeder.” Bu özelliği sebebiyle kalbi ilhamın getirdiği bilgi doğrudur. Müellif kalbi ilhamla ilgili başka bilgiye yer vermez. Yukarıda zikrettiğimiz gibi melekten gelen ilham hakkında da izah yoktur. Ancak nefisten ve şeytandan gelen ilhamın aksine melek ve kalpten gelen ilhamdan endişe duyulmaması gerektiğini söyler. ${ }^{32}$ Şu halde ilhamın bu dörtlü tasnifini temelde iki başlikta, yani nefis ve şeytandan olan ilhamları kötülük ve melekten olan ilhamı ise iyilik başlıkları altında değerlendirmek mümkündür.

İlham için Eşrefoğlu'nun belirlediği beşli taksimin sonuncusu ise Rabbani ilhamdır. Müellifimiz bu ilhamın ancak nefs-i mülhime ma-

${ }^{28}$ Eşrefoğlu Rûmî, Müzekki'n-Nüfûs, s. 49.

${ }^{29}$ Eşrefoğlu Rûmî, Müzekkin-Nüfûs, s. 46.

${ }^{30}$ Eşrefoğlu Rûmî, Müzekki'n-Nüfûs, s. 46.

${ }^{31}$ Eşrefoğlu Rûmî, Müzekki'n-Nüfûs, s. 52.

${ }^{32}$ Eşrefoğlu Rûmî, Müzekkinn-Nüfûs, s. 50. 
kamında gelebileceğini söyler. Bu yüzden taliplerin nefs-i levvame makamını geçmek için çabalaması gereklidir. Çünkü levvame makamının nefsin hem emmare hem de mülhime makamina bakan yönü bulunmaktadır ve emmareye rahatlıkla kayabilir. Nefs-i mülhime makamında gelen ilham da Eşrefoğlu'na göre üç türlüdür: İlki "mutlak ilham”; ikincisi "işaret" ve sonuncusu da "sarih hitap" şeklinde isimlendirilir. Bunlar arasında bir hiyerarşi bulunmaktadır. "Mutlak ilham" nefs-i mülhime makamına yeni ulaşmış kimselerde ortaya çıkar. "İşaret" aynı makamın ortalarında ve "sarih hitap" ise nefs-i mülhimenin sonunda meydana gelmektedir. Eşrefoğlu "sarih hitaba” nail olanların hiçbir şüpheye düşmeden bunun Allah'tan geldiğini bildiklerini söyler. ${ }^{33}$

Şu halde Eşrefoğlu'nun "sarih hitap” olarak belirttiği ilhamın marifetle özdeş görmek mümkündür. Müellifimizin ilhama dair görüşlerini "sarih hitabı" dışarıda bırakılırsa ilk dönem tasavvuf düşüncesindeki "hatır" kavramına genel anlamıyla benzediği söylenebilir. İlk dönemde hatırın kaynakları Allah, melek, şeytan ve nefs olarak geçmektedir. Kelâbâzî bunu şu şekilde ifade eder: "Sûfilerden biri, hâtırların dört şekli vardır, demiştir: "Ulu ve Yüce Allah’tan olan hâtır, melekten olan hâtır, neftsen olan hâtır, düşman ve şeytandan olan hâtır.” Allah'tan olan hâtır; kulu uyarmak, melekten olan hâtır; onu taate teşvik etmek, neftsen olan hâtır; heva ve heves peşinde koşmaya çağırmak, şeytandan olan hâtır ise günahı cazip göstermek şeklinde olur." ${ }^{34}$ Ancak Eşrefoğlu'nun marifeti ifade edecek "sarih hitap" kavramı tasavvufun klasik olarak kabul edilen eserlerinde geçmemektedir. Bu da müellifimizin gündeme getirdiği yeni bir kavramdır; ancak eserde genellikle rabbani ilham şeklinde kendisini göstermektedir.

\subsection{Müzekki'n-Nüfûs'ta Marifete Dair Konular}

Eşrefoğlu Rûmî’nin Müzekkinn-Nüfûs eserine dikkatle eğildiğimizde onun tasavvuf konularına teorik olarak yaklaştığını söylemek pek mümkün değildir. Gerçi kendisi de bu eserini kaleme alma sebebi olarak genel anlamda insanların içinde bulunduğu kötü hal ve

33 Eşrefoğlu Rûmî, Müzekki'n-Nüfûs, s. 50.

${ }^{34}$ Kelâbâzî, Taarruf, s. 149. 
durumdan kurtarmak olduğunu belirtir. Müzekki'n-Nüfûs isimden de anlaşılacağ ele alındığı başlıklardan oluşur. Bu başlıklar içerisinde Eşrefoğlu'nun marifete dair görüşleri de mevcuttur. Şimdi onun marifetle ilgili değindiği konulara geçelim.

Eşrefoğlu marifetin temellendirmesini sahabeye izafe ederek yapmaktadır. Çünkü ona göre sahabe mücahede ve riyazatla nefislerini kötü sıfatlardan temizlemişlerdir. Müellif bu durumdaki sahabeye $\mathrm{Hz}$. Ömer ve Hz. Ali'yi örnek olarak vermektedir. Onlar beşeriyetten hali olup basiret gözünü açmışlardır. Eşrefoğlu Hz. Ömer’in "kalbim rabbimi gördü" ve Hz. Ali'nin "görmediğim rabbe itaat etmem" ifadelerini basiret gözüyle Hakk’1 müşahede ettikten sonra söylediklerini zikreder. Bazı kimselerden ortaya çıkan Hakk'ı görmeye dair tepkiler Eşrefoğlu'nun da dikkatini çekmiştir; ancak o, Hakk'ı müşahede etmenin inkâr edilemeyeceğini özellikle vurgular. ${ }^{35}$

Sahabede ortaya çıkan bu durum sadece onlarla sınırlı değildir. Seyr u süluke giren her kimse marifet dediğimiz bilgiye nail olabilir. Bu konuya dair müellifimiz hem seyr u süluku hem de marifeti içeren ilkeyi Ebû Ali Dekkak’a ait şu sözle açıklamaya çalı̧̧ır: "Dışını mücahede ile süsleyenin içini de Allah müşahede nuruyla süsler." ${ }^{36}$ Bunun yanında yöntem için Eşrefoğlu riyazat ve onun bir unsuru olan açlık, zikir, şeyh, Allah'a yakınlık ve Hz. Peygamber'e ittiba gibi hususlara da değinmektedir. ${ }^{37}$ Müellifimiz marifete dair konularda genelde yönteme bu şekilde atıf yapar. Ancak yönteme dahil olan konuların tam bir şekilde yerine getirilmesi marifet denilen bilgiyi zorunlu olarak ortaya çıkarmamaktadır. Eşrefoğlu Rûmî bu durumu Gazzâli’ye atfettiği "zahiri alimlerin ilimleri çalış1larak kazanılır. Sûfilerin ilmi ise keşfidir"38 sözüyle açıklar.

Eşrefoğlu Rûmî nefsin kötü sıfatlarından arınan kimseye gelen marifetin mahiyetine dair bazı açıklamalarda bulunmaktadır. Bu açık-

${ }^{35}$ Eşrefoğlu Rûmî, Müzekki’n-Nüfûs, s. 43.

${ }^{36}$ Kuşeyrî, er-Risâle, s. 193; Eşrefoğlu Rûmî, Müzekki’n-Nüfûs, s. 320.

${ }^{37}$ Eşrefoğlu Rûmî, Müzekki'n-Nüfûs, s. 42, 50, 299, 438, 560.

${ }^{38}$ Eşrefoğlu Rûmî, Müzekkinn-Nüfûs, s. 300. İlk dönem sûfîlerinden olan Kuşeyrî ve Hücvirî de eserlerinde bu minvalde açıklama yapmışlardır. Bkz.: Kuşeyrî, er-Risâle, s. 147; Ebu'lHasen Ali b. Osman b. Ebi el-Cüllabi el-Hücvirî, Keşfu'l-mahcûb (Hakikat Bilgisi), trc.: Süleyman Uludağ, Dergah Yay., İstanbul 2010, s. 82. 
lamalarda marifet bilgisini olduğu gibi aktarma yoktur; bilginin hangi konularla ilişkili olduğuyla ilgili izahat yer alır. Marifetin mahiyetine dair Eşrefoğlu'nun ifadeleri ilk dönem sûfilerinin görüşlerine benzemektedir. Bunları beş şekilde sıralamak mümkündür. Birincisi Hakk’a dair bilgidir. Müellifimize göre basiret gözü açıldığında Hakk'ın cemali müşahede edilir. ${ }^{39}$ Böylece Hakk'a dair bir bilgi edinilmiş olur. İkincisi bir şeyin gerçekte ne olduğuyla alakalı bilgidir. Bunu görünüş ve gerçeklik olarak belirtmek mümkündür. Yani bir şeyin görünüşü ne olduğuna dair bilgi sunar; ancak aynı şeyin görünüşün ötesinde ifade ettiği gerçeklik vardır ve marifet buna dair bilgi sunar. ${ }^{40}$ Üçüncüsü marifetin gayp aleminden bilgi vermesidir. Dördüncüsü dünya ve ahiretin gerçekliğine dairdir. Beşincisi ise Eşrefoğlu'nun tabiriyle "kurtuluş ve fesad" hakkındadır. ${ }^{41}$ Müellifimiz bununla alakalı ayrıntılı bir bilgi sunmaz. Fakat her iki ifade her iki dünyayı da kapsayabilir. Marifet de buna dair bilgi sunar.

Eşrefoğlu Rûmî marifetin mahiyetine dair yatığ1 açıklamalardan sonra onun her talipte aynı olup olmadığına dair görüşünü zikreder. $\mathrm{Bu}$ görüş de ilk dönem mutasavvıfların düşüncesine genel anlamda uygundur. Müellifimiz bu konudaki düşüncesini kendisine gelen "müşahede bir şekilde mi olur yoksa her talibin kabiliyetine göre değişir mi?” soruya binaen açıklamaktadır. O da müşahedenin herkesin manevi makamına göre olacağını söyler. ${ }^{42}$

Eşrefoğlu herkesin manevi kabiliyetine göre marifetin geleceğini ifade ederken kalbi ön plana çıkarır. Kalp tasavvuf metinlerinde de bilgiyle ilişkili olarak kullanılmaktadır. ${ }^{43}$ Dolayısıyla kalp için marifetin geldiği yer olarak zikretmek yanlış değildir. Eşrefoğlu Rûmî de marifet için aynı kanaate sahiptir. $O$, kalbin iki yöne sahip olduğunu düşünür. Biri duyular alemine bakar. Diğeri de gayp alemine bak-

${ }^{39}$ Eşrefoğlu Rûmî, Müzekki'n-Nüfûs, s. 43.

${ }^{40}$ Eşrefoğlu Rûmî, Müzekki'n-Nüfûs, s. 41.

${ }^{41}$ Eşrefoğlu Rûmî, Müzekki'n-Nüfûs, s. 42.

${ }^{42}$ Eşrefoğlu Rûmî, Müzekki'n-Nüfûs, s. 572. Ebû Nasr es-Serrâc Kur'ân'ın anlamı için de aynı durumun geçerli olduğunu düşünür ve makamına göre anlamın ortaya çıkacağını ifade eder. Bkz.: Ebû Nasr Abdullah b. Ali Muhammed Serrâc et-Tûsî, el-Lüma' (Islam Tasavvufu), trc.: Hasan Kamil Yilmaz, Erkam Yay., İstanbul 2012, s. 93.

${ }^{43}$ Cüneyt el-Bağdâdî marifetin mahallinin kalp olduğu hakkında şu fadeleri zikreder: "Hakk dostlarının gönlü Allah'ın sırrının mahallidir. O sırrını içinde dünya sevgisi bulunan bir kalbe koymaz." Bkz.: Attar, Tezkire, s. 203. 
maktadır. ${ }^{44}$ Gayp alemine bakan yön marifetin içerik olarak taalluk ettiği hususlara dair bilgiyi alır. Kalbin bu bilgileri alması için hem ilk dönem mutasavvıfların hem de Eşrefoğlu'nun zikrettiği "perdelerin” ${ }^{5}$ kalkması gerekir. Dolayısıla perde marifeti engelleyici bir unsur olarak zikredilir.

Kalpten perdelerin kalkmasından sonra oluşan marifetin bazı sonuçları da bulunmaktadır. Bu sonuçlar iki şekilde ifade edilebilir: Birincisi müellifimizin "dünya kederinin gitmesi ve ahiret acısının gönle doğması" şeklinde zikrettiği düşünsel boyuttur. Düşünsel boyut kişinin eylemlerindeki bilincin yetkinliğini de sağlayabilir. Bu açıdan pratik boyuta etkisi vardır. İkincisi ise marifetin semaya sebep olmasıyla fizyolojik boyuttur. Eşrefoğlu rabbani ilhama nail olanların her sesten etkilenerek sema yapabileceğini söyler. Ancak semanın neftsen kaynaklanıp kaynaklanmadığına dikkat edilmelidir; çünkü ona göre nefsten kaynaklanan sema haramdır. ${ }^{46} \mathrm{Bu}$ sebeple marifetin sebep olduğu semayla marifet dışındaki bir sebepten kaynaklanan sema arasında hüküm açısından fark vardır. Bu da marifetin taliplerde meydana getirdiği sonuçtur.

\section{Sonuç}

Eşrefoğlu Rûmî Hacı Bayrâm-1 Velî̀nin yetiştirdiği sûfilerden biri olup tasavvuf alanında eser vermiştir. Onun meşhur ve önemli eseri olan Müzekki'n-Nüfus nefs terbiyesini merkeze alan bir kitaptır. Dolayısıyla seyr u süluk konularını içeren bir karaktere sahiptir. Eşrefoğlu Rûmî eserini bütün kesimlere hitap etmesi ve faydalı olması için özellikle Türkçe yazmıştır.

Müellifin tasavvufun teorik konularına bu eserinde yer vermediği görülmektedir. Dolayısıyla marifet konusu da sistematik biçimde ele alınmamaktadır. Ancak Eşrefoğlu'nun marifete dair görüşleri bu eserde yer yer kendisini göstermektedir. O da marifetin Allah'tan gelen bir bilgi olduğunu kabul eder. Marifete ulaşmak için seyr u sülukun

${ }^{44}$ Eşrefoğlu Rûmî, Müzekki'n-Nüfûs, s. 299.

${ }^{45}$ Ebû Abdurrahmna Muhammed b. Hüseyin es-Sülemî, Tabakâtü's-sûfiłye, trc.: Abdürrezzak Tek, Bursa Akademi Yay., Bursa 2018, s. 77.

${ }^{46}$ Eşrefoğlu Rûmî, Müzekkinn-Nüfûs, s. 52. 
önemine değinir. Öyle ki ona göre bu yöntemden hiçbir zaman taviz verilmemelidir.

Eşrefoğlu Rûmî ilhamı nefsani, şeytani, meleki, kalbi ve rabbani şeklinde beşe ayırmaktadır. Bunların ilk dördü iyilik ve kötülük üst başlığında değerlendirilmektedir. Rabbani ilham ise marifete karşıllk gelecek şeklinde kullanılmıştır. Fakat müellifimizin rabbani ilhamın dışında marifete getirdiği şöyle bir yenilik vardır: Nefs-i mülhime makamında gelen ilhamı mutlak ilham, işaret ve sarih hitap şeklinde üçe ayırır. Bunlardan kesin olanı ve Hakk'tan geldiğine dair şüphe barındırmayanı "sarih hitaptır." Sarih hitap ise özellikle ilk dönem tasavvuf klasik eserlerinde kullanılmamaktadır. Bu anlamda Eşrefoğlu tasavvuf düşüncesi için marifeti ifade eden yeni bir kavramı ortaya koyduğu söylenebilir.

\section{Kaynakça}

Alkan, Harun, "Eşrefoğlu Rumi’nin Müzekki'n-Nüfus Adlı Eserinde Tevbe Kavramı", III. Uluslararası Hacı Bayrâm-ı Veli Sempozyumu Bildiriler Kitabl, Ankara 2018.

Baz, İbrahim, "Eşrefoğlu Rûmî’nin Müzekki’n-Nüfûs İsimli Eserinde Nefs-i Emmâre'nin Özellikleri ve Islahı”, IV. Uluslararası Hacı Bayram-ı Velî Sетровуити, Ankara 2019.

Cebecioğlu, Ethem, Tasavvuf Terimleri ve Deyimleri Sözlüğ̈̈, Otto Yay., Ankara 2014.

Çakmaklığlu, Mustafa, İbn Arabìde Ma'rifetin İfadesi, İnsan yay., İstanbul 2011.

Demirdaş, Öncel, "Hacı Bayrâm-1 Veli'de Dünya Algısı”, II. Uluslararası Hacı Bayram-ı Velì Sempozyumu Bildiriler Kitabı 1, Kalem Neşriyat, Ankara 2017.

Derin, Süleyman, "Hacı Bayram Veli’nin Damadı Eşrefoğlu'nda Nefsin Terbiye Metotları", II. Uluslararası Hacı Bayram-ı Velî Sempozyumu Bildiriler Kitabı 2, Ankara 2017.

Haksever, Ahmet Cahid, "Hac-1 Bayram-1 Veli'nin Şiirlerinde Tasavvufi Mertebeler”, Uluslararası Hacı Bayram-ı Veli Sempozyumu Bildiriler Kitabı 2, Ankara 2016. 
Hücvirî, Ebu'l-Hasen Ali b. Osman b. Ebi el-Cüllabi, Keşfu'l-mahcûb (Hakikat Bilgisi), trc.: Süleyman Uludağ, Dergah Yay., İstanbul 2010.

Işıtan, İbrahim, "Halvetiyye Geleneğine ve Bir Halveti Şeyhi Olan Sofyalı Bâli Efendi’ye Göre Sülukun Yedi Evresi”, Marife: Dini Araştırmalar Dergisi, 2010.

el-Kelâbâzî, Ebû Bekr Muhammed b. İbrâhim el-Buhârî, et-Taarruf (Doğuş Devrinde Tasavvuf), Dergah Yay., İstanbul 2016, s. 174.

el-Kuşeyrî, Ebü'l-Kâsım Zeynülislâm Abdülkerîm b. Hevâzin, er-Risâletü'lkuşeyriyye (Tasavvuf İlmine Dair Kuşeyrî Risâlesi), trc.: Süleyman Uludağ, Dergah Yay., İstanbul 2009.

Kutluer, İlhan, “İlim”, DíA., Türkiye Diyanet Vakfı Yayınları, İstanbul 2000, c. 22, s.109-114.

Manzûr, Fazl Muhammed b. Mükerrem b. Ali el-Ensârî İbn, Lisânü’-arab, Dâru'l-Maârif, Kahire t.y.

el-Mekkî, Ebû Tâlib Muhammed b. Ali b. Atryye el-Hârisî, Kûtü’-kulûb fî muâmeleti'l-mahbûb ve vasfu tarîki'l-mürîd ilâ makâmi't-tevhîd (Kalplerin $A z ı \breve{g}$ l), trc.: Dilaver Selvi-Yakup Çiçek- Ali Kaya, Semerkand Yay., İstanbul 2011.

Nisaburi, Ebu Hamid Feridüddin Muhammed b. Ebi Bekr İbrahim-i, Tezkiretü'l-evliya, trc.: Süleyman Uludağ, Kabalc1 Yay., İstanbul 2007. Süyufi, Abdullah Rumi b. Seyyid Ahmed Eşref b. Seyyid Muhammed, Müzekki'n-Nüfûs, haz.: Ahmet Kasım Fidan, Semerkand Yay., İstanbul 2015.

es-Sülemî, Ebû Abdurrahmna Muhammed b. Hüseyin, Tabakâtü's-sûfiyye, trc.: Abdürrezzak Tek, Bursa Akademi Yay., Bursa 2018.

et-Tûsî, Ebû Nasr Abdullah b. Ali Muhammed Serrâc, el-Lüma'(Islam Tasavvufu), trc.: Hasan Kamil Yilmaz, Erkam Yay., İstanbul 2012.

Uçman, Abdullah, “Müzekki’n-Nüfus”, DİA., Türkiye Diyanet Vakf1 Yayınları, İstanbul 2006, c. 32, s. 245-246.

Uludağ, Süleyman, Tasavvuf Terimleri Sözlüğ̈̈, Kabalcı Yay., İstanbul 2012. Uludağ, Süleyman, "Marifet”, DİA., Türkiye Diyanet Vakfı Yayınları, İstanbul 2003, c. 28, s. 54-56.

Uludağ, Süleyman, “Nefis”, DIA., Türkiye Diyanet Vakfı Yayınları, İstanbul 2006, c. 32 , s. 528-529. 